Lucrările Seminarului Geografic Dimitrie Cantemir

Vol. 45, October 2017, pp. 33-44

http://dx.doi.org/10.15551/lsgdc.v45i0.03

\title{
The particularities of use and management of water resources in the Danube-Black Sea hydrographical space (the sector of Republic of Moldova)
}

\section{Petru Bacal ${ }^{1}$, Iurie Bejan ${ }^{1}$}

${ }^{1}$ Institute of Ecology and Geography of Academy of Science from Chișinău, Republic of Moldova

To cite this article: Bacal, P. \& Bejan, I. (2017). The particularities of use and management of water resources in the Danube-Black Sea hydrographical space (the sector of Republic of Moldova). Lucrările Seminarului Geografic Dimitrie Cantemir, Vol. 45, pp. 33-44. DOI:

10.15551/lsgdc.v45i0.03

To link to this article: http://dx.doi.org/10.15551/lsgdc.v45i0.03 


\title{
THE PARTICULARITIES OF USE AND MANAGEMENT OF WATER RESOURCES IN THE DANUBE-BLACK SEA HYDROGRAPHICAL SPACE (THE SECTOR OF REPUBLIC OF MOLDOVA)
}

\author{
Petru Bacal, Iurie Bejan ${ }^{1}$
}

\begin{abstract}
The hydrographical space Danube-Black Sea (HS DBS) has an insignificant contribution in supplying water to the Republic of Moldova. The reduced share of HS DBS is due both to its small size and to the presence of only small and medium rivers, and to the pronounced agrarian rural character of the region of study. Except the Hadjider river basin, in other river basins and administrative districts from HS DBS, most of waters (> 80\%) are abstracted from underground sources. Over $2 / 3$ of abstracted water is used for agricultural purposes (including $17 \%$ for irrigation), $\approx 1 / 4$ for household and only $3.6 \%$ for technological purposes.
\end{abstract}

Keywords: river basin, water use, agriculture, household

\section{Introduction}

The Danube-Black Sea hydrographical space (DBS HS) includes rivers Cahul, Ialpug, and Kitai, which flow into the estuaries of the Danube, as well as rivers Cogâlnic, Sarata, Hadjider, which turn flow into the Black Sea's estuaries (fig.1). Except for the river Cahul, there are transboundary rivers, starting their courses in the Moldovan territory and extending to the territory of Ukraine. The total area of DBS HS is 6,5 thousand $\mathrm{km}^{2}$, which consists of about $19.3 \%$ of the total area of Republic of Moldova The territory of these basins is characterized by a pronounced diversity of natural, social and economic conditions.

The surface water resources of DBS HS are quite modest. The region covers about $20 \%$ of Moldova's territory, but here are focused only about $1 \%$ of the available surface water resources of the country. The average annual flow is only 76 million $\mathrm{m}^{3}$.

In the DBS HS natural lakes are literally missing. At the same time, in the region of study have been identified 1452 anthropogenic lakes, from which 5 lakes with an area exceeding $1 \mathrm{~km}^{2}, 11$ lakes with surface from 0.5 to $0.99 \mathrm{~km}^{2}$, 1of 1 lakes with an area from 0.25 to $0.49 \mathrm{~km}^{2}$ and 1425 lakes with area under $0,25 \mathrm{~km}^{2}$. The water in many lakes is characterized by a degree of mineralization which may exceed 2.0-5 g/l. In addition, the region of study is affected by intense aridity processes, acute shortage of water, particularly from surface sources.

The total amount of useful groundwater reserves within the HS DBS are 106 thousand $\mathrm{m}^{3} /$ day, of which domestic-drinking water 105 thousand $\mathrm{m}^{3} /$ day water-engineering 8.5 thousand $\mathrm{m}^{3} /$ day [4].

\footnotetext{
${ }^{1}$ Institute of Ecology and Geography of Academy of Science from Moldova (Chișinău),
} 
The total number of population from DBS HS is of about 444 thousand inhabitants or $12.3 \%$ of the total population of the country. The region of study has a low level of urbanizations. The share of urban population is only $28 \%$ of the total population. In addition, all towns (9) from the DBS HS were small and medium sized. Therefore, the studied region has a very strong rural and agricultural character and the degree of urbanization and industrialization is much lower than the rest of the country, which directly impacts on the volume and on the water usage categories.

The present research is based on recent analytical studies on the implementation of the Management Plan of River Basin, which is stipulated in EU Framework Directive [5]. For the study, the author has focused on management plans, which are being implemented, such as the Danube River Basin Management Plan [3], Management Plan of River Space Prut-Bârlad [7], Management Plan of Prut River basin [2].

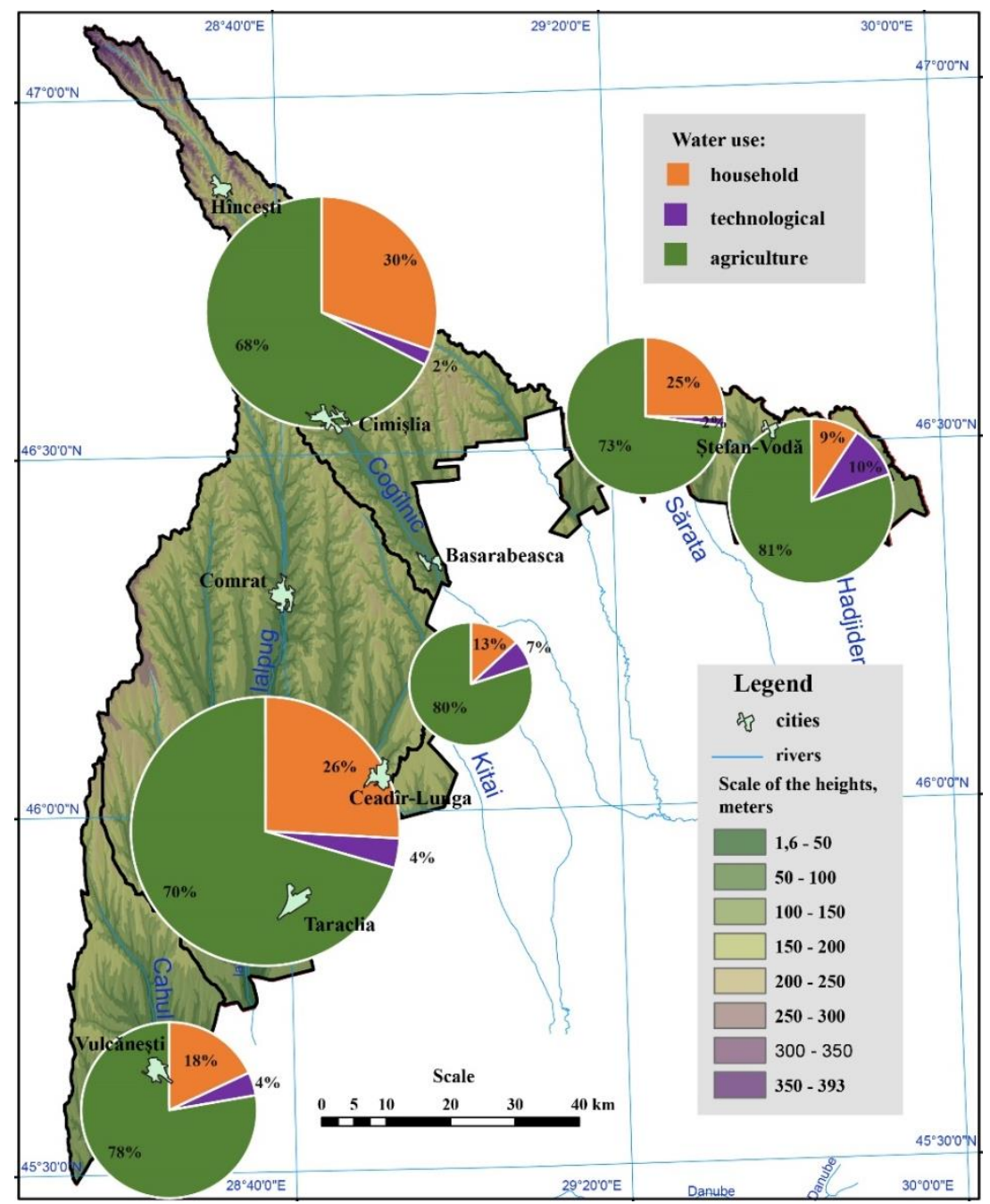

Figure 1: Water use in the river basin of Danube-Black Sea Hydrographical Space 


\section{The dynamics and usage categories of water consumption}

The Danube-Black Sea hydrographical space has an insignificant contribution to supplying water to the Republic of Moldova. Within this basin lies just $1.2 \%$ of the total abstracted and used water from the right bank of the Dniester river - 6-7\% (Table 1).

The reduced share of DBS HS is due both to its small size and to the presence of only small and medium rivers, and to the pronounced agrarian rural character of the region of study. Meanwhile, the respective hydrographical space has a crucial contribution to water supply of households and economic activities, especially agricultural ones from South Region and in the Hâncesti district from Central Region of Republic.

Table 1: The volume and share of captured and used water in the DBS HS (average 2007-2015)

\begin{tabular}{|c|c|c|c|c|c|c|c|c|c|c|c|c|c|c|}
\hline \multirow{3}{*}{$\begin{array}{l}\text { River } \\
\text { basins }\end{array}$} & \multicolumn{4}{|c|}{ Captured water } & \multicolumn{10}{|c|}{ Used water } \\
\hline & \multicolumn{2}{|c|}{ Total } & \multicolumn{2}{|c|}{ groundwater } & \multicolumn{2}{|c|}{ Total } & \multicolumn{2}{|c|}{ household } & \multicolumn{4}{|c|}{ technological agriculture ${ }^{2}$} & \multicolumn{2}{|c|}{ irrigation } \\
\hline & \begin{tabular}{|c|} 
thou- \\
sand $\mathrm{m}^{3}$
\end{tabular} & $\%^{3}$ & $\begin{array}{c}\text { thou- } \\
\text { sand } \mathrm{m}^{3}\end{array}$ & $\%$ & \begin{tabular}{|c|} 
thou- \\
sand $\mathrm{m}$
\end{tabular} & $\%$ & $\begin{array}{c}\text { thou- } \\
\text { sand } \mathrm{m}^{3}\end{array}$ & $\%$ & \begin{tabular}{|c|} 
thou- \\
sand $\mathrm{m}$
\end{tabular} & $\%$ & $\begin{array}{c}\text { thou- } \\
\text { and } \mathrm{m}^{3}\end{array}$ & $\%$ & \begin{tabular}{|c|} 
thou- \\
sand $m$
\end{tabular} & $\%$ \\
\hline Ialpug & 5080 & 3.1 & 4406 & 86 & 4034 & 3.4 & 951 & 24 & 132 & 3.3 & 2598 & U & 280 & 6.7 \\
\hline Cahul & 934 & 0.6 & 537 & 54 & 859 & 0.7 & 122 & 14 & 29 & 3.4 & 527 & 61 & 233 & 27 \\
\hline Cogâln & 2982 & 1.8 & 2636 & 88 & 2678 & 2.3 & 846 & 32 & 60 & 2 & 1883 & 70 & 472 & 18 \\
\hline Kitai & 263 & 0.2 & 254 & 85 & 258 & 0.2 & 34 & 13 & 18 & 6 & 207 & 79 & 7 & 2.6 \\
\hline Sărata & 581 & 0.4 & 471 & 94 & 508 & 0.4 & 127 & 25 & 9 & 1.7 & 369 & 72 & 93 & 18 \\
\hline Hadjider & 623 & 0.4 & 182 & 30 & 618 & 0.5 & 66 & 11 & 73 & 12 & 568 & 92 & 407 & 66 \\
\hline DBS HS & 10464 & 6.5 & 8486 & 82 & 8954 & 7.6 & 2146 & 24 & 321 & 3,6 & 6151 & 68 & 1492 & 17 \\
\hline
\end{tabular}

Sources: Tables 1-2 and Figure 2 are elaborated by the author after data from Generalized Annual Reports on the Indices of water management. Basin Department of the Agency "Apele Moldovei" [8].

With the exception of the Hadjider river basin, in all basins and administrative districts from DBS HS, most of waters (> 80\%) are abstracted from underground sources (table 1). The maximum share of water captured from groundwater sources is observed in the areas of the districts of Cimislia and Hancesti located in the Cogalnic river basin and those of TAU (territorially administrative unit) Gagauzia located in the Ialpug river basin [8]. Because of a very low flow and intensifying processes of climate aridity, the ability to exploit surface sources is very low. In addition, ground waters have increased the mineralization which significantly limits the development of irrigated agriculture.

Despite a fluctuating evolution, conditioned by rainfall and economic situation, in the period under review, there is a pronounced tendency to reduce the total volume of used water, which is valid in the whole basin of DBS HS (Table 2). Overall, the volume of captured water was reduced with $27 \%$ (from 11.4 million $\mathrm{m}^{3}$ to 8.3 million $\mathrm{m}^{3}$ ).

The largest reduction is observed in the basins of small rivers like the Cahul (4 times), the Kitai (2 times) and the Hadjider (38\%) and the smallest reductions in average basins like the Ialpug (20\%) and the Cogalnic (15\%). At the same time, in the Hadjider river basin is attested the positive dynamics of water use volume. In addition, the negative dynamics is interrupted in 2015 in all basins of the region [8] and in the Cogalnic river basin shows a significant increase in the volume of used waters.

\footnotetext{
2 including irrigation

${ }^{3}$ without Transnistria (left bank of Dniester)
} 
Table 2: The dynamics of captured waters in the HS DBS, in million. $m^{3}$

\begin{tabular}{|l|l|l|l|l|l|l|l|l|l|c|}
\hline \multirow{2}{*}{$\begin{array}{c}\text { Hydrographical } \\
\text { basins }\end{array}$} & $\mathbf{2 0 0 7}$ & $\mathbf{2 0 0 8}$ & $\mathbf{2 0 0 9}$ & $\mathbf{2 0 1 0}$ & $\mathbf{2 0 1 1}$ & $\mathbf{2 0 1 2}$ & $\mathbf{2 0 1 3}$ & $\mathbf{2 0 1 4}$ & $\mathbf{2 0 1 5}$ & \multirow{2}{*}{ average } \\
\cline { 2 - 13 } & 4.79 & 3.91 & 4.01 & 4.04 & 4.17 & 4.11 & 3.73 & 3.71 & 3.84 & 4.03 \\
\hline Calpug & 1.65 & 1.36 & 1.51 & 0.71 & 0.5 & 0.61 & 0.56 & 0.41 & 0.42 & 0.86 \\
\hline Cogul & 3.17 & 2.74 & 2.91 & 2.51 & 2.57 & 2.8 & 2.51 & 2.2 & 2.69 & 2.68 \\
\hline Kitai & 0.38 & 0.33 & 0.29 & 0.26 & 0.24 & 0.23 & 0.2 & 0.2 & 0.19 & 0.26 \\
\hline Sărata & 0.5 & 0.46 & 0.71 & 0.52 & 0.39 & 0.52 & 0.47 & 0.48 & 0.52 & 0.51 \\
\hline Hadjider & 0.89 & 0.59 & 0.52 & 0.49 & 0.64 & 0.67 & 0.51 & 0.61 & 0.64 & 0.62 \\
\hline HS DBS & $\mathbf{1 1 3 8}$ & $\mathbf{9 . 3 9}$ & $\mathbf{9 . 9 5}$ & $\mathbf{8 . 5 3}$ & $\mathbf{8 . 5 1}$ & $\mathbf{8 . 9 4}$ & $\mathbf{7 . 9 8}$ & $\mathbf{7 . 6 1}$ & $\mathbf{8 . 3 0}$ & $\mathbf{8 . 9 5}$ \\
\hline
\end{tabular}

The volume of water used for irrigation has registered a strong decreasing trend (fig. 2), especially in medium river basins like the Ialpug and the Cogalnic which has also been reflected on the overall situation in the region of study. In contrast with the water used in agriculture, the amount of water used for domestic purposes shows a positive trend. Following the expansion of rural water supply networks that is supplied almost exclusively from groundwater sources, the volume and percentage of water for domestic utilities is registering an increase. However, a large part of the population is supplied with sewage waters which are widely used in the household, for irrigation of agricultural crops and farm animals and other purposes.

The total volume of used water is, on average, $\approx 9$ million $\mathrm{m}^{3}$ being conditioned by the number and size of the urban centres and monitored irrigated areas in these districts. The maximum volume of water used in TAU Gagauzia is 2,5 million $\mathrm{m}^{3}$, while in the districts of Stefan Voda -1.5 million $\mathrm{m}^{3}$, Taraclia -1.3 million $\mathrm{m}^{3}$ and Cimişlia -1.1 million. $\mathrm{m}^{3}$. The minimum volume of used water is registered in the district of Basarabeasca, which has significantly less dimensions than the other districts of the investigated region, and in the districts of Hancesti, Cantemir and Cahul, of which only a part is located in the DBS HS and the rest is in the Prut river basin.

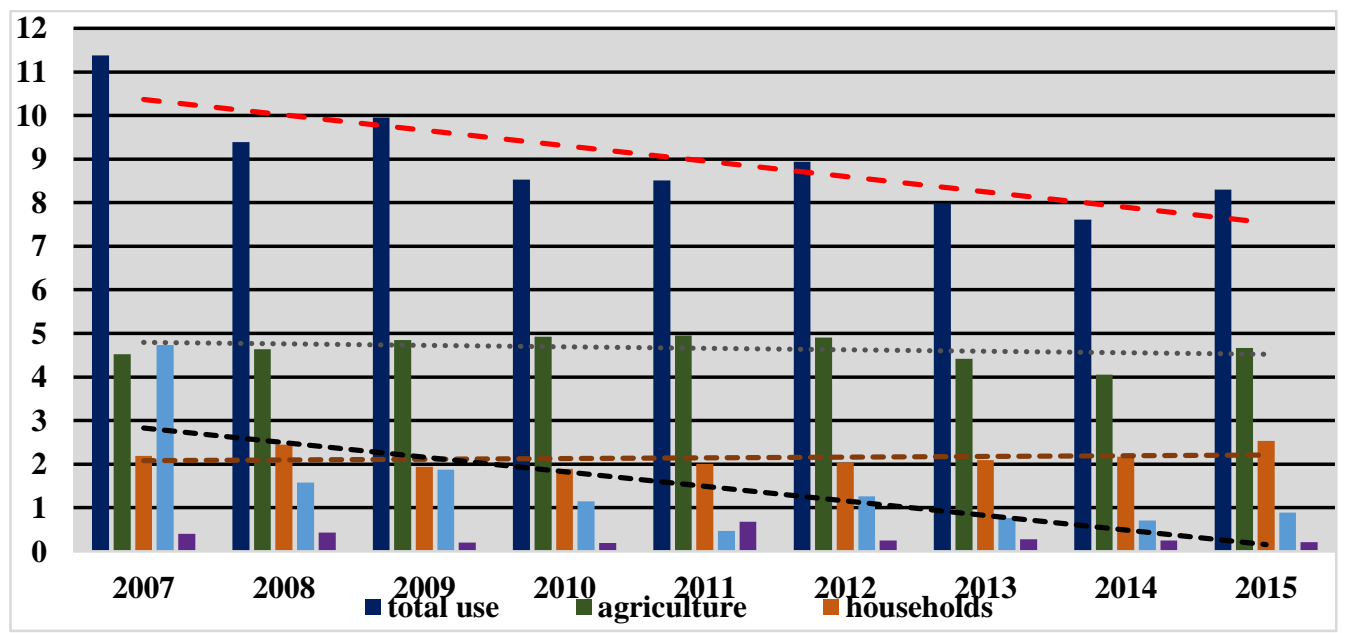

Figure 2: Dynamics, by usage categories, of water used in the DBS HS 
For agricultural needs are used about 6.2 million $\mathrm{m}^{3}$ or $2 / 3$ of total volume. In all river basins and districts, for agriculture uses over $60 \%$ of abstracted water, including Hadjider $92 \%$, Kitai - 79\%, Sărata $-72 \%$ and Cogâlnic $-70 \%$ (Table 1). In all districts of the region of study, agriculture's share exceeds $50 \%$ (Table 2) from the waters used and in half of the regions - 70\%. Therefore, in the DBS HS, the amount of water used in agriculture conditioned, directly, the total volume of water used and their spatial distribution. Outside of the urban area, most of the water is captured by food and agriculture farms for their own needs and by Irrigation Technological Stations (ITS), who serving, as a rule, the big agricultural farms [2].

The volume of water used in agriculture, especially for irrigation, is conditioned by the surface of basins and territorially administrative units inside the respective hydrographical area, the water sources used for these purposes, and the presence of great agricultural farms in the region. Thus, the maximum volume of water used in agriculture is observed in the larger basins of the Cogalnic and the Ialpug rivers, and, accordingly, in the TAU Gagauzia (1.4 million $\mathrm{m}^{3}$ ) and the districts of Cimislia $\left(759\right.$ thousand $\left.\mathrm{m}^{3}\right)$ and Stefan-Voda $\left(1.2\right.$ million $\left.\mathrm{m}^{3}\right)$. For irrigation are used on average 1.5 million $\mathrm{m}^{3}(17 \%)$, including in the river basins Cogâlnic -472 thousand $\mathrm{m}^{3}$ and Hadjider -407 thousand $\mathrm{m}^{3}$. The maximum share of water used for irrigation is found in the river basins Hadjider (66\%) and Cahul (27\%) and at level of administrative districts - in Basarabeasca (36\%) and Stefan-Voda (30\%). The relatively low volume of water used in irrigation is conditioned both by natural conditions (low flow and rainfall shortage, increased risk of soil salinization), and by the technical and economic possibilities of water usage for irrigation in the region.

Within the region there are 157 water reservoirs with the main destination the fishery. Their total area is 3634 ha. The largest area of water basins with fishing destination holds Taraclia up to 1099 ha (30\%), followed by Stefan-Voda and Gagauzia with 976 ha (26\%) and 906 ha $(25 \%)$ respectively. The smallest surface of the water basins with a fishing destination has Basarabeasca district -46.5 ha $(1.3 \%)$. Among the species that live in the region are: pike, crucian carp, silver carp, roach, perch, etc.

For domestic needs are used about $1 / 4\left(2.1\right.$ million $\left.\mathrm{m}^{3}\right)$ of abstracted waters. The biggest volume and share in the Cogalnic (31\%) and Ialpug (24\%) river basins are conditioned by the greater area of these river basins, the presence of urban centres (Hancesti, Cimislia, Basarabeasca and, respectively, Comrat Ceadar- Lunga and Taraclia) in the perimetre of the basins as well as rural settlements which have extensive centralized water supply systems and register water usage. More than half of the total volume of water is captured by the specialized utility companies that supply water not only to inhabitants and budgetary institutions, but also to most industrial companies [9].

As a result of the underdeveloped industry, and also because of the small flows of rivers in the region of study, for technological purposes it is used an insignificant volume of abstracted waters -321 thousand $\mathrm{m}^{3}(3.6 \%)$, especially in wineries, chicken factories, transport companies, commercial and service centers, especially health and education institutions, markets and car washes.

\section{The general framework of water management}

Regulatory and legislative framework for the use and management of water resources, regulating the provision of services of water supply and sewerage is stipulated in Water Law no. 272 of 23.12.2011, Law no. 1102 of 06.02.1997 on Natural Resources, Law no. 272 of 
10.02.1999 on Drinking Water, Law no. 1440 of 27.04.1995 on the River and Water-Basin Water Protection Areas and Strips, Law no. 303 of 12.13.2013 on public services of water supply and sewerage, Law no. 397 of 16.10.2003 on Local Public Finance, Title VIII of the Tax Code with respect to the Tax Liabilities for Natural Resources Fees, Decision no. 741 of National Agency for Energy Regulation (NAER) from18.12.2014 on "Methodology of determination, approval and application of tariffs for public water supply, sewerage and waste water treatment services" and application of tariffs for public water supply services, sewerage systems and wastewater treatment.

Water Low is elaborated in accordance with EU Directives on the use and management of water resources, particularly the Water Framework Directive (2000/60/EC), Urban Waste Water Treatment Directive (91/271/EEC), the Directive on the Assessment and Management of Flood Risks (2007/60/EC). According to Articles 6 and 54 of this law, water resources management is based on the principles of "polluter pays" and the economic value of water that involves the cost recovery of water resources management, as well as the principle of sustainable water use. The principle of economic value substitutes the one of "beneficiary pays" for primary users and, in case of paid water supply and sewerage service provision, for secondary ones.

Regulating water supply and sewerage public service is provided by the National Agency for Energy Regulation (NAER). NAER's main tasks in this field are: a) development, extension and withdrawal of activity licenses from water supply and sewerage system operators; b) to develop methodology for determination and application of tariffs for these service; c) to verify and approve tariffs for water supply and sewerage established by operators and approved by the local councils, including current expenditure and investment justification. If the local council approves tariffs at a lower level than prime-cost of these service, it is obliged to establish in its decision of tariff approvement the source and specific amount to be allocated to the operators to cover their lost incomes due to low tariffs.

Core competencies of local public authorities (LPA): a) approvement, in accordance with the ANRE's methodology, the tariffs for public water supply and sewerage services; b) management of these services, based on competitiveness and management efficiency; c) approves functioning specifications and regulations for the local operators; $h$ ) allocates compensation for some household consumer categories that are considered vulnerable.

The main powers of the Agency "Apele Moldovei" are: a) to develop policies and strategies for the use and protection of water resources; b) to apply the water resources basin management; c) to design, build and repair the water supply and sewerage systems, irrigation and drainage systems, reservoirs and protection dams; d) to keep data recording of water fund; e) to elaborate the State Water Cadastre; f) to approve the general and special water use authorizations; g) to coordinate the management of transboundary water resources; $h$ ) to provide management assistance and logistics to achievement the objective and goal stipulated in the Strategy Regarding Water Supply and Sanitation.

\section{The production indices of water supply services}

In the Republic of Moldova, water supply services are provided by: 1) enterprises of the Association „Moldova Apa-Canal”; 2) Irrigation Technical Stations that contribute to mass water supply to large agricultural farms, but the infrastructure is mostly worn or damaged; 3 ) Industrial enterprises, particularly sugar factories in the North Region, mining enterprises and 
those producing of building materials etc.; 4) Water Users' Associations in rural areas; 5) small specialized enterprises or individuals operating the water supply and sewerage systems in rural areas and some small and medium towns.

Information regarding the territorial services of water supply and sewage is wholly accumulated only in business association "Apa Canal" [6]. They contribute with more than $2 / 3 \%$ of the supplied drinking water and over $80 \%$ of the discharged and purified wastewater volume (Table 3). The contribution of other categories of providers is established on the basis of index table of water management in the annual reports of the territorial statistical and environmental authorities [1], [9].

Number of communal water supply systems in the districts located within the DBS HS is 204 units, of which over $90 \%$ are in operation. The most water supply enterprises are registered in the districts of Cimislia (62), Stefan-Voda (37) and TAU Gagauzia (38), while the fewest are in the districts of Hancesti and Cahul, where the most settlements are outside the DBS HS. The total length of water supply network is $2410 \mathrm{~km}$, of which $1 / 4(635 \mathrm{~km})$ are owned by the municipal enterprises "Apa-Canal" located in urban centres. The largest aqueducts are registered in TAU Gagauzia $(863 \mathrm{~km})$, in the districts of Cimislia $(385 \mathrm{~km})$ and Stefan Voda $(290 \mathrm{~km})$, which is conditioned primarily by the number and size of urban centres and rural settlements located within this hydrographical area and have centralized systems for water supply. Minimum length of aqueducts is found in the districts of Cahul $(87 \mathrm{~km})$ and Cantemir $(121 \mathrm{~km})$, where in the recent years, are being implemented major extension projects for water supply and sanitation networks, particularly in the rural area.

Table 3: Status of water supply systems in the DBS HS (2015)

\begin{tabular}{|c|c|c|c|c|c|c|c|c|c|c|}
\hline \multirow{3}{*}{ TAU } & \multirow{3}{*}{$\begin{array}{c}\text { Number of } \\
\text { water supply } \\
\text { systems }\end{array}$} & \multicolumn{2}{|c|}{$\begin{array}{c}\text { Aqueducts } \\
\text { length, } \\
\text { in km }\end{array}$} & \multicolumn{2}{|c|}{$\begin{array}{l}\text { Consumption, } \\
\text { liters/inhabitant }\end{array}$} & \multicolumn{4}{|c|}{$\begin{array}{l}\text { Pumping stations (PS) and } \\
\text { artesian wells (AW) }\end{array}$} & \multirow{3}{*}{$\begin{array}{c}\text { Access of } \\
\text { population } \\
\text { to the } \\
\text { water } \\
\text { supply } \\
\text { systems , \% }\end{array}$} \\
\hline & & \multirow[b]{2}{*}{ total } & \multirow{2}{*}{$\begin{array}{l}\text { Apă- } \\
\text { Canal }\end{array}$} & \multirow[b]{2}{*}{ total } & \multirow[b]{2}{*}{$\begin{array}{l}\text { Apă- } \\
\text { Canal }\end{array}$} & Nur & ber & Capacity & & \\
\hline & & & & & & PS & AW & $\begin{array}{l}\text { thousand } \\
\mathrm{m}^{3} / \text { day }\end{array}$ & Used & \\
\hline Hâncești & 8 & 206 & 122 & 6,0 & 45,8 & 35 & 25 & 12,4 & 12,5 & 25 \\
\hline Cimislia & 62 & 385 & $\begin{array}{c}46, \\
3\end{array}$ & 9,3 & 31,5 & 70 & 75 & 23,2 & 20,6 & 43 \\
\hline Basarabeasca & 16 & 191 & $\begin{array}{c}34 \\
6\end{array}$ & 12,5 & 24,9 & 25 & 30 & 16,4 & 55,5 & 37 \\
\hline Cantemir & 20 & 121 & - & 2,3 & - & 25 & 26 & 10 & - & 30 \\
\hline Cahul & 10 & 87 & - & 9,0 & - & 10 & 10 & 6 & - & 23 \\
\hline Taraclia & 13 & 267 & $\begin{array}{c}57 \\
8\end{array}$ & 8,8 & 37,1 & 43 & 60 & 13,3 & 21 & 69 \\
\hline TAU Găgăuzia & 38 & 863 & 329 & 8,6 & & 135 & 145 & 28,4 & - & 67 \\
\hline Comrat & 1 & - & 122 & - & 42,7 & 20 & 18 & - & 47,3 & - \\
\hline Ceadâr-Lunga & 1 & - & 161 & - & 36 & 42 & 39 & - & 16 & - \\
\hline Vulcănești & 1 & - & 46 & 4,4 & 20,3 & 20 & 18 & - & 29,2 & - \\
\hline Ștefan-Vodă & 37 & 290 & $\begin{array}{c}45 \\
8\end{array}$ & 7,0 & 44,8 & 27 & 30 & 12 & 11 & 52 \\
\hline Total & 204 & 2410 & 635 & 7,5 & 35,4 & 370 & 401 & 122 & 27 & 61 \\
\hline
\end{tabular}

Sources: tables 3-4 are elaborated by the author on the basis of NBS Reports on the water supply and sewerage systems, amac.md 


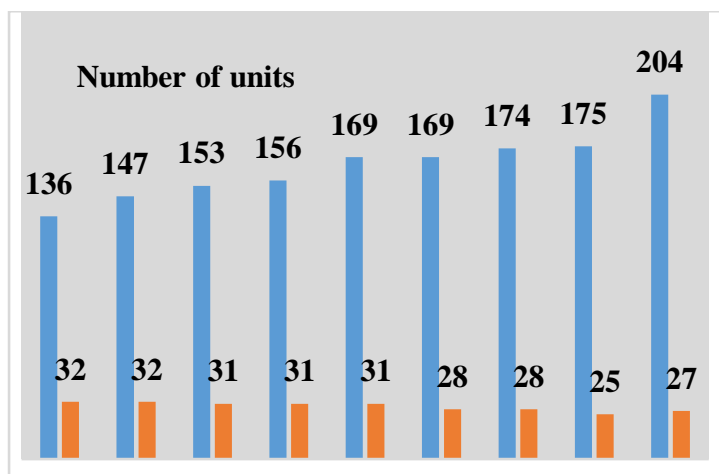

200720082009201020112012201320142015 water supply sewerage

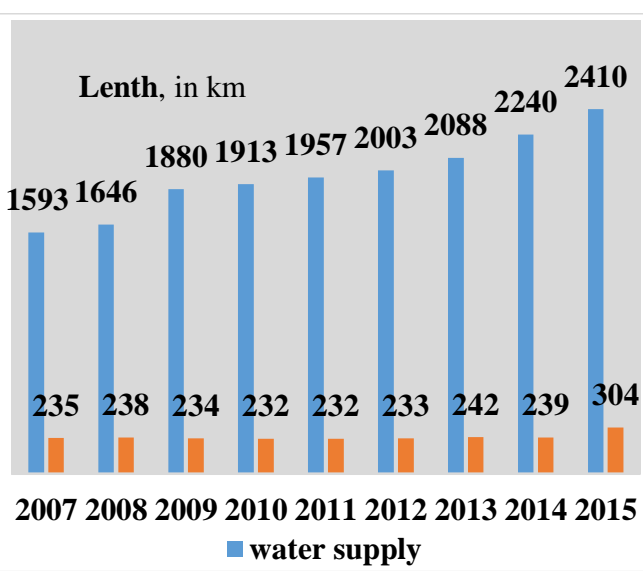

Figure 3: Dynamics of water supply and sewerage systems in the DBS HS (2015), in units and km

Source: elaborated by the author on the basis of NBS Reports on the water supply and sewerage systems

In the years 2007-2015, the number of centralized water supply systems grew with 50\%, from 136 to 204 units (Fig. 3). Also, the length of these systems has increased with over 50\%, or from $1593 \mathrm{~km}$ to $2410 \mathrm{~km}$. The maximum increase (2 times) in number and length of centralized water supply systems is registered in the districts of Cantemir, Cahul, Hincesti and Stefan Voda, while in Taraclia is registered a decrease of these indicators.

If we consider the recent projects completed or nearing completion supported by NEF, ARD and other sources of financing, the pace of infrastructure rehabilitation and expansion of centralized water supply is significantly high. It is important that these plausible input indicators to turn into successful indicators, such as increased access to quality water and services, improved state of water resources and bodies etc. [2].

Despite the rapid expansion of water supply networks, water consumption per capita is very low - only 7.5 litres [1] or about $50 \%$ less than the country average, which is explained by lower degree of urbanization and the high share of rural population, which has reduced access to centralized water supply systems and, especially, to those of centralized wastewater discharge and sanitation. In the urban settlements serviced by the enterprises of "Moldova Apa-Canal" Association, per capita consumption is about 35.4 litres [6] or about 5 times higher than the average consumption in this basin, but more than 3 times lower than the country average. Also, only $61 \%$ of the population of systems the DBS HS has access to centralized water supply systems (Table 3). In TAU Gagauzia and the district of Taraclia the access of population to water supply systems over-goes $67 \%$, while in the districts of Hancesti, Cantemir and Cahul this indicator does not exceed 30\%. Discrepancies mentioned above emphasize the ethno-geopolitical connotations of the Soviet period that require immediate and consistent removal.

In the DBS HS water is supplied by 370 pumping stations and 401 fountains, with a total capacity of $122000 \mathrm{~m}^{3} /$ day similar to that of the Prut river basin (120 $000 \mathrm{~m}^{3} /$ day) [2]. At the same time, it is used only about $1 / 4$ of the project capacities of existing stations, which is explained by the high degree of wear and tear as well as the multiple decrease of water consumption in agriculture and industry in the last two decades. The enterprises of the "Moldova Apa-Canal" Association have over one third (121) of pumping stations and artesian wells (147) in this hydrographical area. 
The total volume of water supplied in the DBS HS is, on average, 4,7 million $\mathrm{m}^{3}$ (Table 4), 37\% of which are supplied by "Apa-Canal" enterprises. Water supplied volume is determined by the number and size of urban centres and drinking water supplies from their proximity as well as the number of users in rural settlements in the perimeter of this region connected to the centralized water supply systems and water consumption for different household needs including the agricultural ones. Thus, the maximum volume of water is supplied in Gagauzia (1.7 million $\mathrm{m}^{3}$ ), in the districts of Cimislia $\left(707\right.$ thousand $\left.\mathrm{m}^{3}\right)$ and Stefan Voda (470 thousand $\mathrm{m}^{3}$ ), while the minimum volume in the settlements of the districts of Cantemir (110 thousand $\left.\mathrm{m}^{3}\right)$, Cahul $\left(360\right.$ thousand $\mathrm{m}^{3}$ ) and Hanceşti $\left(370\right.$ thousand $\mathrm{m}^{3}$ ) most of which are located outside the DBS HS.

The volume of water supplied by the enterprises of "Moldova Apa-Canal" Association is 1.7 million $\mathrm{m}^{3}$ [6], which represent only $2.6 \%$ of all these enterprises in the Republic (66.2 million $\mathrm{m}^{3}$ ). It depends on demographic and economic dimensions of serviced urban centres located inside the perimeter of the DBS HS and water resources available in their proximity. Thus, the maximum volume of water supplied by the municipal enterprises in the cities of Comrat (409 thousand), Ceadir-Lunga (301 thousand $\mathrm{m}^{3}$ ) and Hancesti (289 thousand $\mathrm{m}^{3}$ ), while the minimum volume in the smaller cities of Basarabeasca (114 thousand $\mathrm{m}^{3}$ ) and Vulcăneşti $\left(124\right.$ thousand $\left.\mathrm{m}^{3}\right)$.

For population there are supplied 4.2 million $\mathrm{m}^{3}$ or $\approx 90 \%$ of the total, inclusively 1.5 million $\mathrm{m}^{3}$ by the enterprises "Apa-Canal". This proportion is similar in the all districts and towns of the DBS HS. The second position is shared by the economic and budgetary organizations, which are provided annually nearly 230 thousand $\mathrm{m}^{3}$ or nearly $5-7 \%$ of the total.

Table 4: Using of water supply systems in the DBS HS (2015)

\begin{tabular}{|c|c|c|c|c|c|c|c|c|c|c|c|}
\hline \multirow{4}{*}{ TAU } & \multicolumn{8}{|c|}{ Supplied water volume, thousand $\mathrm{m}^{3}$} & \multirow{3}{*}{$\begin{array}{l}\text { Loss of } \\
\text { abstracted } \\
\text { water, } \%\end{array}$} & \multicolumn{2}{|c|}{ Degree of, in \% } \\
\hline & \multicolumn{2}{|l|}{ Total } & \multicolumn{2}{|c|}{ Population } & \multicolumn{2}{|c|}{$\begin{array}{l}\text { Budgetary } \\
\text { organizations }\end{array}$} & \multicolumn{2}{|c|}{$\begin{array}{l}\text { Economic } \\
\text { agents }\end{array}$} & & & Using of \\
\hline & \multirow[t]{2}{*}{ total } & \multirow{2}{*}{$\begin{array}{l}\text { Apă- } \\
\text { Canal }\end{array}$} & \multirow[t]{2}{*}{ total } & \multirow{2}{*}{$\begin{array}{l}\text { Apă- } \\
\text { Canal }\end{array}$} & \multirow[t]{2}{*}{ total } & \multirow{2}{*}{$\begin{array}{l}\text { Apă- } \\
\text { Canal }\end{array}$} & \multirow[t]{2}{*}{ total } & \multirow{2}{*}{$\begin{array}{l}\text { Apă- } \\
\text { Canal }\end{array}$} & & assets & asse \\
\hline & & & & & & & & & \multicolumn{3}{|c|}{ Apă-Canal } \\
\hline Hâncesti & 370 & 289 & 310 & 246 & 34 & 22,7 & 26 & 20,5 & 33,7 & 24 & 0,27 \\
\hline Cimislia & 707 & 165 & 643 & 139 & 32,1 & 6,2 & 32,1 & 19,2 & 50,5 & 23 & 0,04 \\
\hline Basarabeasca & 398 & 114 & 364 & 108 & 6,2 & 3,5 & 28,6 & 2,1 & 44,1 & 61 & 0,19 \\
\hline Cahul & 360 & - & 320 & - & 22 & - & 18 & - & - & - & - \\
\hline Cantemir & 110 & - & 92 & - & 7 & - & $\overline{0,6}$ & - & - & - & - \\
\hline Taraclia & 522 & 202 & 474 & 175 & 20,9 & 13,1 & 27,8 & 13,8 & 23,2 & 75 & 0,13 \\
\hline UTA Găgăuzia & 1718 & 833 & 1561 & 725 & 86,3 & 48,6 & 71,4 & 59,3 & - & - & - \\
\hline Comrat & - & 409 & & 346 & - & 29,6 & - & 33,3 & 27 & 38 & 0,09 \\
\hline Ceadâr-Lunga & - & 301 & & 268 & - & 15,5 & - & 16,7 & 33 & 14 & 0,06 \\
\hline Vulcănești & - & 124 & & 111 & - & 3,5 & - & 9,3 & 48 & 31 & 0,16 \\
\hline Ștefan-Vodă & 470 & 139 & 430 & 125 & 27 & 7,4 & 13 & 6,8 & 25,7 & 73 & 0,17 \\
\hline Total DMN & 4656 & 1741 & 4193 & 1518 & 236 & 102 & 218 & 122 & 36 & 42 & 0,14 \\
\hline
\end{tabular}

The volume of water delivered to economic agents is determined by the number and production capacity of the enterprises that lack their own sources of water, particularly agricultural and complex markets, service stations, car washes, gas stations, etc. Among 
budgetary organizations are to be mentioned the medical and training centres and the buildings of local and district administration.

Irrevocable losses exceed, on average, $3 / 4$ of the total captured water, which is far higher than the country average share $(21 \%)$, including the right bank of the Dniester river $(55 \%)$. The large volume of technological losses is due to the more advanced depreciation of the water supply infrastructure in the DBS HS as well as technological specifics of the water supply in agriculture that prevails in the branch structure of this basin.

Despite their great share, we can see a considerable reduction of irrevocable losses of captured water [8]. Only in the years 2007-2015, total irrevocable losses of water in the Prut river basin was reduced with over one quarter. The maximum reduction $(>60 \%)$ of total water losses is registered in the river basins where is a predominant supply from surface sources as the Hadjider and the Cahul. Similar to captured water, the volume losses register a downward trend, greater $(\approx 40 \%)$ losses in technology, particularly in irrigation. Losses in water transportation have decreased slightly.

Irrevocable losses of captured and distributed water by enterprises "Apa-Canal" from the DBS HS are approximately $36 \%$ if to compare with the average of $78 \%$ of all registered enterprises for water supply in this basin. This difference is explained by the fact that "ApaCanal" supplies water mostly to the household in urban areas, where technical losses are significantly lower than those of water supply in agriculture, especially irrigation.

The amount of losses and the degree of infrastructure usage (fixed assets) of water supply and sanitation systems is conditioned, to a large extent, by wear and damage degree, as well as the low efficiency of strategic and operational management of concerned enterprises (table 4). Therefore, the maximum loss is observed in the cities of Cimislia (50\%), Vulcăneşti $(48 \%)$ and Basarabeasca (44\%). Wear degree of fixed assets is on average $42 \%$ or with $6 \%$ lower than the country average. This is explained by the massive expansion and modernization of water supply networks in the rural area whose population is greatly predominant (70\%) in this basin perimeter.

Another difficult issue is the low usage (27\%) of fixed assets, which is conditioned both by multiple decrease of industrial consumption and by the value - money disproportionate ratio in the most enterprises "Apa-Canal". The significant increase in tariffs for these services, which is not accompanied by a corresponding increase in quality and efficiency, requires businesses and large organizations to build their own systems of water supply or seek for other operators, even in the private sector.

\section{Conclusions}

The Danube-Black Sea hydrographical space consists of small and medium rivers with relatively low flow, which limit their massive use for various purposes, especially, production. Over $2 / 3$ of abstracted water is used for agricultural purposes (inclusively $17 \%$ for irrigation), $\approx 1 / 4$ for domestic purposes and only $3.6 \%$ for technological purposes.

In the analyzed period, the volume of water abstracted and used is found a significant reduction, which is conditioned, notably, by similar reducing of water abstracted volume from surface sources and used for different agricultural activities, especially for irrigation.

Despite of recent significant expansion of supply water network, most of the rural population continue to use polluted water from wells. In addition, much of the water supply networks in rural areas are not filled with the centralized sewerage networks and wastewater 
treatment plants, which increases the harmful impact on the natural environment and the human body.

As a result of the predominant agricultural usage and massive usage of technology and worn water pipes, the volume of water loss is averagely of 8,2 million $\mathrm{m}^{3}$ or $78 \%$ of the total captured water. At the same time, the significant decrease of surface waters used in agriculture has conditioned the similar reduction of water volume loss.

\section{References}

1. Activitatea sistemelor de alimentare cu apă şi de canalizare în anii 2007-2015. In: statistica.md.

2. Bejan Iu., Boboc N., Bacal P. et al., 2016. Planul de gestionare al bazinului hidrografic Prut. Ciclul I, 2017-2022.Chișinău, 2016, 116 p.

3. Danube River Basin Management Plan. In: icpdr.org/main/publications/danube-river-basinmanagement-plan.

4. 2010. Ghidul Nr. 18. Indrumări cu privire statutul și tendința de evaluare a apelor subterane. Raport tehnic $2010-042$

5. 2003, Guidance document no. 1. Economics and the Environment. The Implementation Challenge of the Water Framework Directive. Luxembourg:

6. 2016. Indicii financiari şi de producţie ai activităţii întreprinderilor de alimentare cu apă şi canalizare ale Asociaţiei ,,Moldova Apă-Canal. Chişinău, 110 p.

7. 2016. Planul de management al spațiului hidrografic Prut Bârlad. In: www.rowater.ro

8. Rapoartele anuale generalizate privind Indicii de gospodărire a apelor în Republica Moldova. Direcţia bazinieră a Agenţiei,,Apele Moldovei”. (2007-2015).

9. Rapoartele anuale privind calitatea factorilor de mediu şi activitatea Agenţiilor şi Inspecţiilor Ecologice (2003-2015). 
